\title{
Cloning and expression of the PHA synthase gene from a locally isolated Chromobacterium sp. USM2
}

\author{
Bhubalan, K., ${ }^{*}$ Kam, Y. C., Yong, K. H. and Sudesh, K. \\ Ecobiomaterial Research Laboratory, School of Biological Sciences, Universiti Sains Malaysia, 11800 Penang, Malaysia. \\ Email: kesavenb@gmail.com
}

Received 9 October 2009; received in revised form 25 November 2009; accepted 26 November 2009

\begin{abstract}
Chromobacterium sp. USM2, a locally isolated bacterium was found to synthesize poly(3-hydroxybutyrate-co-3hydroxyvalerate), $\mathrm{P}(3 \mathrm{HB}-\mathrm{co}-3 \mathrm{HV})$ copolymer with high $3 \mathrm{HV}$ monomer composition. The PHA synthase gene was cloned and expressed in Cupriavidus necator $\mathrm{PHB}^{-} 4$ to investigate the possibilities of incorporating other monomer. The recombinant successfully incorporated 3-hydroxyhexanoate $(3 \mathrm{HHx})$ monomer when fed with crude palm kernel oil (CPKO) as the sole carbon source. Approximately $63 \pm 2 \mathrm{wt} \%$ of $\mathrm{P}(3 \mathrm{HB}-\mathrm{co}-3 \mathrm{HHx})$ copolymer with $4 \mathrm{~mol} \%$ of $3 \mathrm{HHx}$ was synthesized from $5 \mathrm{~g} / \mathrm{L}$ of oil after $48 \mathrm{~h}$ of cultivation. In addition, $\mathrm{P}(3 \mathrm{HB}-\mathrm{co}-3 \mathrm{HV}-\mathrm{co}-3 \mathrm{HHx})$ terpolymer with $9 \mathrm{~mol} \% 3 \mathrm{HV}$ and $4 \mathrm{~mol} \% 3 \mathrm{HHx}$ could be synthesized with a mixture of CPKO and sodium valerate. The presence of $3 \mathrm{HV}$ and $3 \mathrm{HHx}$ monomers in the copolymer and terpolymer was further confirmed with ${ }^{+} \mathrm{H}-\mathrm{NMR}$ analysis. This locally isolated PHA synthase has demonstrated its ability to synthesize $\mathrm{P}(3 \mathrm{HB}-\mathrm{co}-3 \mathrm{HHx})$ copolymer from a readily available and renewable carbon source; CPKO, without the addition of $3 \mathrm{HHx}$ precursors.
\end{abstract}

Keywords: Chromobacterium sp., poly(3-hydroxybutyrate-co-3-hydroxyvalerate), poly(3-hydroxybutyrate-co-3-hydroxyhexanoate), crude palm kernel oil, sodium valerate

\section{INTRODUCTION}

Extensive studies have been carried out since the discovery of polyhydroxyalkanoate (PHA) early last century to exploit this intriguing microbial polymer. This naturally occurring carbon and energy storage compound is found in various bacteria and its formation is known to be induced usually by unfavorable growth conditions (Anderson and Dawes, 1990; Doi, 1990). The identification of various hydroxyalkanoate (HA) units besides 3-hydroxybutyrate (3HB) proved to have major impact on the research of this bacterial reserve polymer (Sudesh et al., 2000). To date, around 150 different PHA monomers have been reported (Steinbüchel and LütkeEversloh, 2003). These monomers are classified into two groups based on the number of carbon atoms in their chemical structure. Those containing 3-5 carbon atoms are deemed as short-chain-length (SCL) PHA while medium-chain-length (MCL) PHA consists of 6-14 carbon atoms (Steinbüchel and Lütke-Eversloh, 2003).

PHA that resembles the main commodity plastics (e.g. polypropylene and polystyrene) can be designed and synthesized to suit numerous applications ranging from stiff packaging goods to highly elastic materials for coating (Sudesh and Iwata, 2008). Due to its thermal stability, PHA can be heat-processed using similar technologies in the current plastic industry with an added advantage of complete biodegradability in the natural environment (Doi, 1990; Sudesh et al., 2000). PHAs can be produced from renewable resources such as sugars and plant oils (Loo and Sudesh, 2007a). Attractive properties of PHA make it a suitable substitute for some of the petrochemical-based synthetic plastics. Among the various types of PHA, poly(3-hydroxybutyrate-co-3-hydroxyhexanoate) [P(3HBco-3HHx)] has been shown to possess useful properties such as softness and flexibility (Doi et al., 1995). In addition, it has also been demonstrated that $\mathrm{P}(3 \mathrm{HB}-\mathrm{co}-$ $3 \mathrm{HHx}$ ) having low molar fraction of $3 \mathrm{HHx}$ can be produced from vegetable oils as the sole carbon source without having to add $3 \mathrm{HHx}$ precursors (Fukui and Doi, 1998).

Production of PHA by both Gram negative and Gram positive bacteria have been investigated and well documented. Besides this, isolation and identification of new bacterial strains with better PHA production capabilities are also being continuously investigated. In a recent study, a locally isolated Cupriavidus strain from the Malaysian environment had been evaluated for the production of PHA copolymer from various carbon sources (Vigneswari et al., 2009). Amongst the documented PHA producing microorganisms, the strain of interest related to this study is Chromobacterium violaceum. It was identified as a PHA producer and is known to populate the soil and water in areas of tropical biodiversity around the world (Kolibachuk et al., 1999). It was reported that $C$. violaceum can produce polymer composed primarily of $3 \mathrm{HB}$ and 3-hydroxyvalerate (3HV) while being capable of accumulating poly(3hydroxyvalerate) $[\mathrm{P}(3 \mathrm{HV})]$ homopolymer when grown in valerate (Steinbüchel et al., 1993; Kolibachuk et al., 1999). C. violaceum is also known to accumulate $3 \mathrm{HV}$ and trace 
amounts of $3 \mathrm{HHx}$ from odd or even carbon numbered fatty acids (Kolibachuk et al., 1999). The complete genome of $C$. violaceum has been sequenced and annotated (Vasconcelos et al., 2003). The cloning and molecular analysis of the $C$. violaceum PHA synthase and heterologous expression of the cloned gene in Escherichia coli, Klebsiella aerogenes, P. putida (phaC mutant) and Cupriavidus necator $\mathrm{PHB}^{-} 4$ (phaC mutant) have been investigated (Kolibachuk et al., 1999).

In this study, a locally isolated Chromobacterium sp. USM2 has been evaluated for its ability to synthesize PHA, and subsequently its PHA synthase gene was cloned and expressed in $C$. necator $\mathrm{PHB}^{-} 4$. Unlike in the previous study whereby $3 \mathrm{HHx}$ was produced from fatty acids (Kolibachuk et al., 1999), here we demonstrate that up to $4 \mathrm{~mol} \%$ of $3 \mathrm{HHx}$ could be produced by the recombinant $C$. necator $\mathrm{PHB}^{-} 4$ using crude palm kernel oil (CPKO) as the sole carbon source. The usage of a renewable and cheaper carbon source such as CPKO compared to fatty acids could aid in reducing the overall production cost of $\mathrm{P}(3 \mathrm{HB}-\mathrm{co}-3 \mathrm{HH})$. Besides this, CPKO is mainly used in the oleochemical industries, thus the bioconversion of CPKO to PHA will not affect the food industry.

\section{MATERIALS AND METHODS}

\section{Isolation and characterization of Chromobacterium sp. USM2}

Fresh water samples from 4 different locations in the northern peninsular of Malaysia were obtained. The samples were plated on nutrient rich (NR) agar (Doi et al., 1995) after serial dilution and incubated at room temperature for $24-48 \mathrm{~h}$. Visible colonies were picked and purified by re-culturing to obtain single colonies. Subsequently, the isolates were screened for PHA production via one-stage cultivation. Isolates were precultured in $50 \mathrm{~mL}$ NR medium. Growth of the cells was monitored by determining the optical density (OD) at the wavelength of $600 \mathrm{~nm}$ and upon reaching $\mathrm{OD}_{600 \mathrm{~nm}}$ of 3.0 , $3 \%(\mathrm{v} / \mathrm{v})$ of the inoculum was transferred into Schlegel's medium consisting of the following components: per liter; $9.0 \mathrm{~g}$ of $\mathrm{Na}_{2} \mathrm{HPO}_{4} \cdot 12 \mathrm{H}_{2} \mathrm{O}, 1.5 \mathrm{~g}$ of $\mathrm{KH}_{2} \mathrm{PO}_{4}, 0.1 \mathrm{~g}$ of $\mathrm{NH}_{4} \mathrm{Cl}, 0.2 \mathrm{~g}$ of $\mathrm{MgSO}_{4} \cdot 7 \mathrm{H}_{2} \mathrm{O}, 0.02 \mathrm{~g}$ of $\mathrm{CaCl}_{2} \cdot 2 \mathrm{H}_{2} \mathrm{O}$, $0.0012 \mathrm{~g}$ of $\mathrm{C}_{6} \mathrm{H}_{8} \mathrm{O}_{7} \cdot \mathrm{Fe}(\mathrm{III}) \cdot \mathrm{NH}_{3}$ and $10 \mathrm{~mL} / \mathrm{L}$ of trace element solution consisting of the following components: per liter of $0.1 \mathrm{M} \mathrm{HCL} ; 500 \mathrm{mg}$ of EDTA, $200 \mathrm{mg}$ of $\mathrm{FeSO}_{4} \cdot 7 \mathrm{H}_{2} \mathrm{O}, \quad 10 \mathrm{mg}$ of $\mathrm{ZnSO}_{4} \cdot 7 \mathrm{H}_{2} \mathrm{O}, 3 \mathrm{mg}$ of $\mathrm{MnCl}_{2} \cdot 4 \mathrm{H}_{2} \mathrm{O}, 30 \mathrm{mg}$ of $\mathrm{H}_{3} \mathrm{BO}_{3}, 20 \mathrm{mg}$ of $\mathrm{CoCl}_{2} \cdot 6 \mathrm{H}_{2} \mathrm{O}, 1$ $\mathrm{mg}$ of $\mathrm{CuCl}_{2} \cdot 2 \mathrm{H}_{2} \mathrm{O}, 2 \mathrm{mg}$ of $\mathrm{NiCl}_{2} \cdot 6 \mathrm{H}_{2} \mathrm{O}$ and $3 \mathrm{mg}$ of $\mathrm{Na}_{2} \mathrm{MoO}_{4} \cdot 2 \mathrm{H}_{2} \mathrm{O}$. The culture was supplemented with 10 $\mathrm{g} / \mathrm{L}$ of glucose. Cultivation was carried out in $50 \mathrm{~mL}$ of Schlegel's medium in $250 \mathrm{~mL}$ conical flask and incubated at $30{ }^{\circ} \mathrm{C}$ at $150 \mathrm{rpm}$ on a reciprocal shaker. PHA production was screened by observing $\mathrm{PHA}$ granules in the cells using $1 \%(\mathrm{w} / \mathrm{v})$ Nile Blue A staining method (Ostle and Holt, 1982). In addition, biochemical characterization and 16S RNA sequencing was carried out to identify and characterize the isolated bacterium. The API 20 NE kit (Biomérieux Co.) was used according to the protocol supplied by the manufacturer. Isolation of genomic DNA (gDNA) was carried out as described by Sambrook et al. (1989). The gDNA was then used as template for PCR amplification of the 16S rRNA fragment. The PCR product obtained was gel purified with the QIAquick (Qiagen, USA) and sequenced at First Base Laboratory (Biosyntech), Malaysia. The nucleotide sequence was compared with those in the GenBank database by using the National Centre for Biotechnology Information (NCBI) Blast program.

\section{Bacterial strains, plasmids and growth conditions}

The bacterial strains and plasmids used in this study are listed in Table 1. E. coli was grown at $37^{\circ} \mathrm{C}$ in LuriaBertani medium consisting of the following components: per liter; $10 \mathrm{~g}$ casein enzymic hydrolysate, $5 \mathrm{~g}$ yeast extract and $10 \mathrm{~g} \mathrm{NaCl}$ at $\mathrm{pH} 7.0$ while Chromobacterium sp. USM2 and $C$. necator $\mathrm{PHB}^{-} 4$ were grown at $30^{\circ} \mathrm{C}$ in NR medium. Cultures were incubated on a reciprocal shaker at $200 \mathrm{rpm}$. Kanamycin $(50 \mathrm{mg} / \mathrm{L})$ was added when necessary to maintain plasmid stability. For maintenance purpose, bacterial cultures from the exponential growth phase were stored at $-20{ }^{\circ} \mathrm{C}$ in $20 \%$ (v/v) glycerol.

For PHA biosynthesis, two-stage cultivation was employed. Chromobacterium sp. USM2 strain was first grown in $50 \mathrm{~mL}$ NR medium to increase cell biomass. After $24 \mathrm{~h}$ of cultivation, cells were harvested and transferred aseptically after rinsing twice with sterile distilled water into Schlegel's medium supplemented with various carbon sources. Sugars such as glucose (10 g/L), fructose $(10 \mathrm{~g} / \mathrm{L})$ and the salt form of $3 \mathrm{HV}$-precursors namely sodium valerate $(10 \mathrm{~g} / \mathrm{L})$ and sodium propionate $(5 \mathrm{~g} / \mathrm{L})$ were filter-sterilized. Meanwhile, valeric acid (1 $\mathrm{g} / \mathrm{L})$, hexanoic acid $(10 \mathrm{~g} / \mathrm{L})$ and CPKO (5 g/L) which is rich in saturated and unsaturated fatty acids were sterilized by autoclaving. The carbon sources were added during inoculation according to their respective concentrations. Cultures were grown at $30^{\circ} \mathrm{C}$ at $200 \mathrm{rpm}$ for $48 \mathrm{~h}$. After $48 \mathrm{~h}$ of cultivation, cells were harvested by centrifugation (6000 $\times \mathrm{g}, 4^{\circ} \mathrm{C}$ for $5 \mathrm{~min}$ ). After being washed with hexane to remove residual oils (for culture supplemented with CPKO), the cells were rinsed with distilled water before lyophilization. Lyophilized cells were subjected to methanolysis for $140 \mathrm{~min}$ at $100{ }^{\circ} \mathrm{C}$ in the presence of methanol/sulfuric acid $(85: 15 \mathrm{v} / \mathrm{v})$. The total amount of PHA and its composition were determined by using gas chromatography (GC) with caprylic methyl ester as an internal standard (Braunegg et al., 1978). Total cell biomass was determined by measuring cell dry weight (CDW).

\section{DNA manipulation, plasmid construction and} nucleotide sequence analysis

Isolation of total genomic DNA (gDNA) from Chromobacterium sp. USM2, plasmid DNA isolation, agarose gel electrophoresis and transformation of $E$. coli were carried out according to standard procedures 
Table 1: Bacterial strains and plasmids used in this study

\begin{tabular}{|c|c|c|}
\hline $\begin{array}{l}\text { Bacterial strains and } \\
\text { plasmids }\end{array}$ & Relevant phenotype & Source or reference \\
\hline \multicolumn{3}{|l|}{ Bacterial strains } \\
\hline $\begin{array}{l}\text { Escherichia coli } \\
\text { JM109 }\end{array}$ & 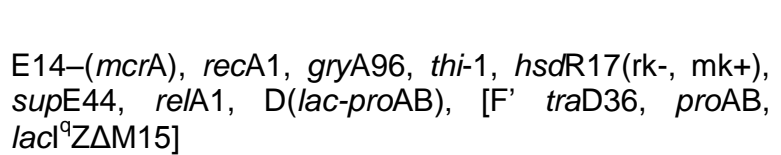 & Stratagene \\
\hline$S 17-1$ & $\begin{array}{l}\text { recA and tra genes of plasmid RP4 integrated into } \\
\text { chromosome; auxotrophic for praline and thiamine }\end{array}$ & Simon et al., 1983 \\
\hline Chromobacterium sp. USM2 & Wild type & This study \\
\hline $\begin{array}{l}\text { Cupriavidus necator } \\
\mathrm{H} 16 \\
\mathrm{PHB}^{-4}\end{array}$ & $\begin{array}{l}\text { Wild type } \\
\text { PHA-negative mutant of } \mathrm{H} 16\end{array}$ & $\begin{array}{l}\text { ATCC } 17699 \\
\text { DSM } 541\end{array}$ \\
\hline \multicolumn{3}{|l|}{ Plasmids } \\
\hline pGEM-T easy & $\begin{array}{l}\text { recA, endA1, gyrA96, thi, hsdR } 17\left(\mathrm{r}_{\mathrm{K}^{-}}, \mathrm{m}_{\mathrm{K}_{+}}\right) \text {, relA1, } \\
\text { supE } 44, \Delta(\text { lac-proAB }),\left[\mathrm{F}^{\prime}, \text { traD36, proAB, lacl }{ }^{9} \mathrm{Z} \Delta \mathrm{M}_{1} 15\right]\end{array}$ & Promega \\
\hline pBBR1MCS-2 & $\mathrm{Km}^{\mathrm{r}}$, broad host range, lac $\mathrm{POZ}$ & Kovach et al., 1995 \\
\hline pGEM-C2 & $\begin{array}{l}\text { pGEM-T easy vector derivative harboring } \\
\text { approximately } 2.0 \mathrm{~kb} \text { fragment of phaC from } \\
\text { Chromobacterium } \mathrm{sp} \text {. with putative promoter }\end{array}$ & This study \\
\hline pBBR1MCS-C2 & $\begin{array}{l}\text { pBBR1MCS-2 derivative harboring approximately } 2.0 \\
\text { kb fragment of phaC from Chromobacterium sp. with } \\
\text { putative promoter }\end{array}$ & This study \\
\hline
\end{tabular}

(Sambrook et al., 1989). Restriction enzymes were used according to the manufacturers' protocols such as Promega and New England Biolabs, respectively. The whole gDNA of Chromobacterium sp. USM2 was used as the template for PCR amplification of its PHA synthase gene (phaC $C_{c s}$ ) using a pair of domain-specific primers designed using NCBI as a reference. Following are the sequences of the primers used; Forward primer (F1): $5^{\prime}$ cgtaattggggcccatgcag- $3^{\prime}$ and Reverse primer (R1): 5'agccgccgccgaagcttccgatggc-3'. PCR was carried out using Peltier Thermal Cycler (PTC-200). The amplified fragment was purified using SpinClean ${ }^{\mathrm{TM}}$ Gel Extraction Kit. The purified fragment approximately $2.0 \mathrm{~kb}$ was then ligated into pGEM-T easy cloning vector (Promega) according to the manufacturer's protocol. The derived pGEM-C2 plasmid was then digested with Apal and Sall to obtain phaC $C_{\mathrm{Cs}}$ with sticky ends. The digested product was then introduced into the Apal-Sall digested sites of the broad-host-range vector pBBR1MCS-2 (Kovach et al., 1995). Hence, the pBBR1MCS-C2 plasmid was constructed for the functional expression of phaC $C_{\mathrm{Cs}}$ in $C$. necator $\mathrm{PHB}^{-} 4$. DNA sequencing was carried out by the dideoxy chain termination method with the Prism 310 DNA sequencer (Applied Biosystems, Inc.) employing the dye terminator labeling procedure (Perkin Elmer Corp.).

\section{Functional expression of Chromobacterium sp. USM2 PHA synthase gene in $C$. necator $\mathrm{PHB}^{-} 4$}

Plasmid pBBR1MCS-C2 was introduced into $C$. necator $\mathrm{PHB}^{-} 4$ as described in (Friedrich et al., 1981). For PHA biosynthesis, one-stage cultivation was employed. $C$. necator $\mathrm{PHB}^{-} 4$ strain harboring pBBR1MCS-C2 was first precultured in NR medium (Doi et al., 1995) for $12 \mathrm{~h}$ before being transferred ( $3 \%[\mathrm{v} / \mathrm{v}])$ into a $250 \mathrm{~mL}$ flask containing $50 \mathrm{~mL}$ mineral medium (MM) (Doi et al., 1995). C. necator strains are known to grow and produce PHA from carbon substrates such as sugars or plant oils. Hence, fructose and CPKO were chosen as carbon substrates for PHA production using this recombinant. CPKO or fructose was added to the culture medium at a final concentration of $5 \mathrm{~g} / \mathrm{L}$ when fed as the sole carbon source and $2.5 \mathrm{~g} / \mathrm{L}$ respectively in the presence of precursor. Sodium valerate $(2.5 \mathrm{~g} / \mathrm{L})$ was added at $24 \mathrm{~h}$ as precursor for the generation of $3 \mathrm{HV}$ monomer. Kanamycin (50 mg/L) was added to maintain plasmid stability. Cultures were grown at $30^{\circ} \mathrm{C}$ at $200 \mathrm{rpm}$ for $48 \mathrm{~h}$. After 48 $\mathrm{h}$ of cultivation, the cells were harvested, lyophilized and subjected to GC analysis as mentioned earlier.

\section{Nuclear Magnetic Resonance (NMR)}

The PHA accumulated in the cells was first extracted by refluxing lyophilized cells with chloroform for $4 \mathrm{~h}$ at $60^{\circ} \mathrm{C}$. After filtration, the chloroform extract was concentrated 
and the dissolved PHA was precipitated in chilled methanol. A total of $25 \mathrm{mg}$ of PHA sample was dissolved in $1 \mathrm{~mL}$ of deuterated chloroform $\left(\mathrm{CDCl}_{3}\right)$. The ${ }^{1} \mathrm{H}$ NMR spectrum was measured on a Bruker AVANCE 300; NC, USA spectrometer at $400 \mathrm{MHz}$ at $30{ }^{\circ} \mathrm{C}$. Tetramethylsilane $\left(\mathrm{Me}_{4} \mathrm{Si}\right)$ was used as an internal chemical shift reference.

\section{Electron microscopic analysis (TEM)}

TEM analysis was carried out to observe the accumulation of PHA granules and the changes in cell morphology under the electron microscope (Philip CM 12/ STEM and JLM-2000FX11). Cells were harvested and fixed in McDowell-Trump fixative at $4{ }^{\circ} \mathrm{C}$ for $24 \mathrm{~h}$ (McDowell and Trump, 1976). The cell pellets were then post-fixed with $1 \%$ osmium tetroxide $\left(\mathrm{OsO}_{4}\right)$ at room temperature. Cells were dehydrated in an increasing ethanol series $(50,75$, 95 and $100 \%$ ) and then transferred to $100 \%$ acetone. Cells were embedded at $60^{\circ} \mathrm{C}$ for $24-48 \mathrm{~h}$ in Spurr's low viscosity resin (Spurr, 1969). Ultra-thin sections were prepared, mounted on copper grids and stained with uranyl acetate and lead citrate for electron microscope examination at an acceleration voltage of $80 \mathrm{kV}$ (Philip CM 12/ STEM and JLM-2000FX11).

\section{RESULTS AND DISCUSSION}

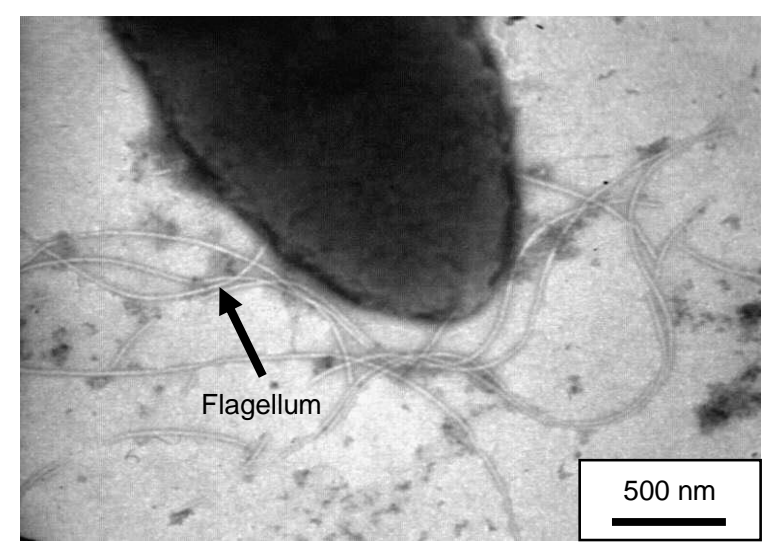

Figure 1: TEM image showing the presence of flagella on Chromobacterium sp. USM2

\section{Isolation and screening of PHA producing strain}

Eight bacterial isolates were obtained from the fresh water samples which were spread on NR agar plates. These isolates were grown in Schlegel's medium which was supplemented with $10 \mathrm{~g} / \mathrm{L}$ of glucose. Among the cultured isolates, only one which was obtained from the Seven Wells waterfall, Langkawi Island emitted bright orange fluorescence with Nile Blue A under fluorescence microscope. This suggests the presence of PHA-like granules in the bacterium. Morphological and biochemical tests were done to identify the isolate. Colonies on the NR agar were violet pigmented, circular with entire edge, convex and the surface was smooth and glistering. The diameter of the colonies ranged between $0.5 \mathrm{~mm}$ to 1.0 $\mathrm{mm}$. Meanwhile, the cells were motile by means of flagella (Figure 1), non-spore forming and rod-shaped (1.5 $\mu \mathrm{m}-3$ $\mu \mathrm{m} \times 0.4 \mu \mathrm{m}-0.5 \mu \mathrm{m})$. According to the biochemical tests, the isolate was determined as Gram negative, non-lactose fermenting aerobic bacterium. Optimum growth was observed at $30{ }^{\circ} \mathrm{C}$. The isolate was then identified as $C$. violaceum with an accuracy of $99.9 \%$ based on the API 20 NE kit results which were interpreted using Apiweb ${ }^{T M}$ stand alone V1.2.1 software. The partial 16S rRNA sequence (GenBank accession no. FJ668944) further confirmed this with $98 \%$ similarity to $C$. violaceum. The isolate was denoted as Chromobacterium sp. USM2 and deposited in Japanese Culture Collection with the accession number of JCM 15051.

\section{Nucleotide sequence of Chromobacterium sp. USM2 PHA synthase gene}

The phaC Cs consisting of 1704 nucleotides was successfully cloned using the pair of domain-specific primers. The gene encoded a protein of 568 amino acids which is the PHA synthase, PhaC. The Shine-Dalgarno (S/D) sequence GGAAGA was located 37 nucleotides upstream of the start codon ATG. According to the $C$. violaceum genome project (Brazilian Genome, 2009), there are six pairs of identified promoters in the phaC gene of $C$. violaceum. The probable promoter pair in phaCcs was located 57 bp upstream of the start codon with the sequence of (GTTTCA-17N-CAGAAT), which was identified as -35 and -10 region respectively. TGA was the stop codon for this gene. The phaC $C_{C s}$ sequence was aligned with various known PHA producers such as; Aeromonas caviae, Alcaligenes latus, Burkholderia sp. DSMZ9242, C. violaceum, C. necator, Delftia acidovorans, Paracoccus denitrificans and Streptomyces aureofaciens using Clustal $X$. The alignment formed 3 clustals and it was found that $p h a C_{\mathrm{Cs}}$ of the isolated Chromobacterium sp. USM2 was in the same clustal as $D$. acidovorans with similarity of $84 \%$. It is interesting to note that the phaC $C_{\mathrm{Cs}}$ is in a different clustal from $C$. violaceum even though it has high similarity of $89 \%$.

The phaC $C_{\mathrm{Cs}}$ was successfully introduced into the broad-host-range vector pBBR1MCS-2 for the construction of pBBR1MCS-C2 plasmid which was later used for functional expression of phaC $C_{\mathrm{Cs}}$ in $C$. necator $\mathrm{PHB}^{-4}$.

\section{PHA accumulation by Chromobacterium sp. USM2 from various carbon sources}

The ability of Chromobacterium sp. USM2 to synthesize PHA from various carbon sources was investigated (Table $2)$. It has been reported that $C$. violaceum produces poly(3-hydroxybutyrate-co-3-hydroxyvalerate) [P(3HB-co$3 \mathrm{HV})$ ] copolymer when glucose or fructose was fed as sole carbon source (Kolibachuk et al., 1999). However, Chromobacterium sp. USM2 only accumulated $\mathrm{P}(3 \mathrm{HB})$ 
Table 2: Biosynthesis of PHA by Chromobacterium sp. USM2 from various carbon sources ${ }^{\mathrm{a}}$

\begin{tabular}{|c|c|c|c|c|}
\hline \multirow[t]{2}{*}{ Carbon sources } & \multirow[t]{2}{*}{ Cell dry weight (g/L) } & \multirow[t]{2}{*}{ PHA content $^{0}(w t \%)$} & \multicolumn{2}{|c|}{ PHA compositions (mol\%) } \\
\hline & & & 3HB & 3HV \\
\hline Glucose & $3.0 \pm 0.2$ & $22 \pm 4$ & 100 & 0 \\
\hline Fructose & $2.8 \pm 0.2$ & $14 \pm 2$ & 100 & 0 \\
\hline Valeric acid & $2.9 \pm 0.1$ & $10 \pm 2$ & 12 & 88 \\
\hline Hexanoic acid & $2.7 \pm 0.2$ & $2 \pm 1$ & 100 & 0 \\
\hline Sodium valerate & $3.1 \pm 0.2$ & $32 \pm 2$ & 2 & 98 \\
\hline Sodium propionate & $2.8 \pm 0.1$ & $2 \pm 1$ & 62 & 38 \\
\hline CPKO & $3.0 \pm 0.2$ & $23 \pm 4$ & 100 & 0 \\
\hline
\end{tabular}

3HB, 3-hydroxybutyrate; 3HV, 3-hydroxyvalerate

ancubated for $48 \mathrm{~h}$ at $30^{\circ} \mathrm{C}$, initial pH 7.0, $200 \mathrm{rpm}$ in Schlegel's medium.

${ }^{\mathrm{b}} \mathrm{PHA}$ content in freeze-dried cells

homopolymer up to $22 \pm 4 \mathrm{wt} \%$ and $14 \pm 2$ wt $\%$ from glucose and fructose, respectively. C. violaceum is also known to accumulate $3 \mathrm{HV}$ and trace amounts of $3 \mathrm{HHx}$ in saturated and unsaturated fatty acids (Loo et al., 2005) to determine the possibility of $3 \mathrm{HV}$ and $3 \mathrm{HHx}$ from odd or even carbon numbered fatty acids (Kolibachuk et al., 1999). Therefore, Chromobacterium sp. USM2 was fed with hexanoic acid and CPKO which is rich incorporation. However, it was found that Chromobacterium sp. USM2 could not incorporate neither $3 \mathrm{HV}$ nor $3 \mathrm{HHx}$ monomers from hexanoic acid or CPKO. The bacterium accumulated only 23 wt\% of $\mathrm{P}(3 \mathrm{HB})$ from $\mathrm{CPKO}$ while a very low amount of $\mathrm{P}(3 \mathrm{HB})$ was produced with hexanoic acid (Table 2). The results suggested that the Chromobacterium sp. USM2 has PHA synthesizing abilities that differ slightly from that of the $C$. violaceum reported by Kolibachuk et al. (Kolibachuk et al., 1999). $\mathrm{P}(3 \mathrm{HB}-\mathrm{co}-3 \mathrm{HV})$ copolymer was successfully produced by cultivating Chromobacterium sp. USM2 in known 3HV-precursors such as sodium valerate, sodium propionate or valeric acid as the sole carbon source. Based on the results shown in Table 2, the effect of the carbon sources on PHA content and 3HV composition could be arranged in the following order: sodium propionate $<$ valeric acid < sodium valerate. Higher PHA content (32 $\pm 2 \mathrm{wt} \%$ ) and $3 \mathrm{HV}$ composition (98 mol\%) was obtained when the isolate was fed with $1.0 \%$ sodium valerate. Sodium valerate was the better precursor for high $3 \mathrm{HV}$ generation. This observation was consistent with the biosynthetic pathways where activated valerate (valeryl-CoA) could be directly incorporated as a monomeric unit since propionyl-CoA instead of acetyl-CoA is the final product of the $\beta$-oxidation cycle (Steinbüchel and Lütke-Eversloh, 2003).

According to Kolibachuk and co-workers, $C$ violaceum accumulated highest $3 \mathrm{HV}$ monomer composition of $95 \mathrm{~mol} \%$ with a copolymer content of 15 wt\% from heptanoic acid (Kolibachuk et al., 1999). In this study, Chromobacterium sp. USM2 was found to accumulate $98 \mathrm{~mol} \%$ of $3 \mathrm{HV}$ from sodium valerate with a copolymer content of $32 \pm 2 \mathrm{wt} \%$. However, in the presence of valeric acid, the $3 \mathrm{HV}$ composition and $\mathrm{PHA}$ content were lower at $88 \mathrm{~mol} \%$ and $10 \pm 2 \mathrm{wt} \%$, respectively. In a previous study by Park and co-workers,

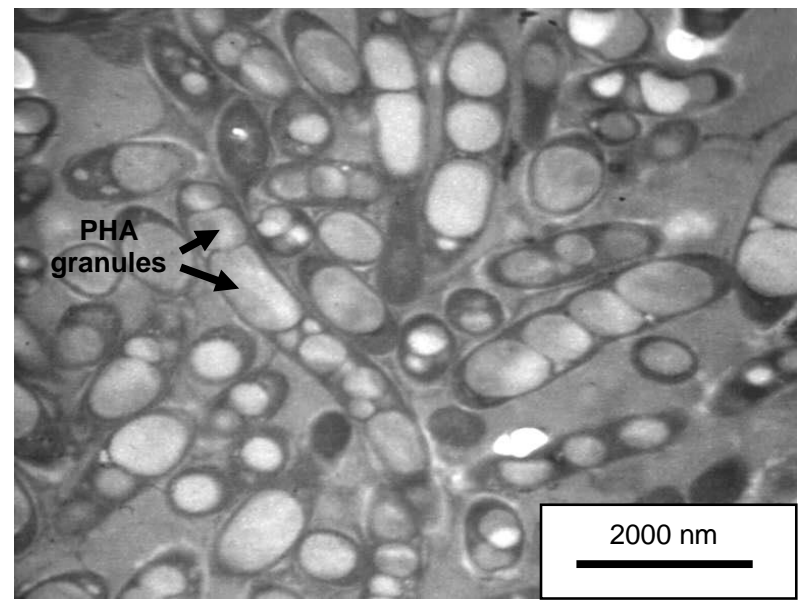

Figure 2: TEM image of $C$. necator $\mathrm{PHB}^{-4}$ harboring pha $C_{\mathrm{Cs}}$ containing $\mathrm{P}(3 \mathrm{HB})$ granules after $48 \mathrm{~h}$ cultivation with $5 \mathrm{~g} / \mathrm{L}$ of fructose at $30^{\circ} \mathrm{C}$.

it was found that valeric acid exhibited some level of inhibitory effect on cell growth (Park et al., 2001). The toxicity effect of the valeric acid was reduced by converting it from acid form to its salt form according to Loo and Sudesh (Loo and Sudesh, 2007b). Different concentrations of sodium valerate ranging from $5 \mathrm{~g} / \mathrm{L}$ to 15 $\mathrm{g} / \mathrm{L}$ were fed to the bacterial culture in order to determine the effects on 3HV composition and copolymer production. However, the varying concentrations did not register any significant changes on the $3 \mathrm{HV}$ molar fraction. Higher concentrations of sodium valerate may have exerted some toxic effect on the bacterial culture since there was a decrease in cell biomass and PHA content (results not shown).

The type of PHA produced by a certain microorganism is determined by not only the PHA synthase but also the metabolic pathways of that microorganism. In order to determine the ability of the Chromobacterium sp. USM2 PHA synthase to incorporate other monomers, phaC $C_{\mathrm{Cs}}$ was expressed in $C$. necator $\mathrm{PHB}^{-} 4$. 
Table 3: Biosynthesis of PHA by C. necator $\mathrm{PHB}^{-} 4$ harboring the PHA synthase gene of Chromobacterium sp. USM2 ${ }^{\mathrm{a}}$

\begin{tabular}{|c|c|c|c|c|c|c|}
\hline \multirow[t]{2}{*}{$\begin{array}{l}\text { Carbon } \\
\text { sources }\end{array}$} & \multirow[t]{2}{*}{ Strains } & \multirow[t]{2}{*}{$\begin{array}{l}\text { Cell dry weight } \\
(\mathrm{g} / \mathrm{L})\end{array}$} & \multirow[t]{2}{*}{$\begin{array}{l}\text { PHA content } \\
{\text { (wt } \%)^{b}}^{b}\end{array}$} & \multicolumn{3}{|c|}{$\begin{array}{l}\text { PHA compositions } \\
\text { (mol\%) }\end{array}$} \\
\hline & & & & $3 \mathrm{HB}$ & $3 \mathrm{HV}$ & $3 \mathrm{HHx}$ \\
\hline Fructose & $\begin{array}{l}\text { C. necator } \mathrm{PHB}^{-} 4 \\
\text { (pBBR1MCS-C2) } \\
\text { C. necator } \mathrm{H}^{-} 6 \\
\text { C. necator } \mathrm{PHB}^{-4} 4 \\
\text { (pBBR1MCS-2) }\end{array}$ & $\begin{array}{l}3.1 \pm 0.2 \\
3.3 \pm 0.1 \\
2.3 \pm 0.2\end{array}$ & $\begin{array}{c}64 \pm 2 \\
56 \pm 1 \\
0\end{array}$ & $\begin{array}{c}100 \\
100 \\
-\end{array}$ & $\begin{array}{l}- \\
-\end{array}$ & $\begin{array}{l}- \\
- \\
-\end{array}$ \\
\hline $\begin{array}{l}\text { Fructose + } \\
\text { Sodium } \\
\text { valerate }\end{array}$ & $\begin{array}{l}\text { C. necator } \mathrm{PHB}^{-} 4 \\
\text { (pBBR1MCS-C2) } \\
\text { C. necator } \mathrm{H} 16\end{array}$ & $\begin{array}{l}2.8 \pm 0.2 \\
3.0 \pm 0.1\end{array}$ & $\begin{array}{l}57 \pm 2 \\
38 \pm 2\end{array}$ & $\begin{array}{l}40 \\
65\end{array}$ & $\begin{array}{l}60 \\
35\end{array}$ & $\begin{array}{l}- \\
-\end{array}$ \\
\hline CPKO & $\begin{array}{l}\text { C. necator } \mathrm{PHB}^{-} 4 \\
\text { (pBBR1MCS-C2) } \\
\text { C. necator } \mathrm{H} 16\end{array}$ & $\begin{array}{l}4.0 \pm 0.2 \\
5.1 \pm 0.4\end{array}$ & $\begin{array}{l}63 \pm 2 \\
60 \pm 1\end{array}$ & $\begin{array}{l}96 \\
100\end{array}$ & - & $\begin{array}{l}4 \\
-\end{array}$ \\
\hline $\begin{array}{l}\text { CPKO + } \\
\text { Sodium } \\
\text { valerate }\end{array}$ & $\begin{array}{l}\text { C. necator } \mathrm{PHB}^{-} 4 \\
\text { (pBBR1MCS-C2) } \\
\text { C. necator } \mathrm{H} 16\end{array}$ & $\begin{array}{l}3.7 \pm 0.3 \\
4.8 \pm 0.3\end{array}$ & $\begin{array}{l}42 \pm 2 \\
40 \pm 3\end{array}$ & $\begin{array}{l}87 \\
91\end{array}$ & 9 & 4 \\
\hline
\end{tabular}

3HB, 3-hydroxybutyrate; 3HV, 3-hydroxyvalerate; 3H Hx, 3-hydroxyhexanoate

${ }^{a}$ Incubated for $48 \mathrm{~h}$ at $30^{\circ} \mathrm{C}$, initial pH 7.0, $200 \mathrm{rpm}$ in MM. Sodium valerate was added at $24 \mathrm{~h}$ of cultivation.

${ }^{\mathrm{b}} \mathrm{PHA}$ content in freeze-dried cells

\section{Expression of Chromobacterium sp. USM2 PHA synthase gene in $C$. necator $\mathrm{PHB}^{-4}$}

Expression of the cloned phaC $C_{\mathrm{Cs}}$ in $C$. necator $\mathrm{PHB}^{-} 4$ complemented the recombinant strain and resulted in accumulation of PHA. The yields and PHA composition produced by the recombinant strain were compared with that of the wild type $C$. necator $\mathrm{H} 16$ (Table 3). The recombinant $C$. necator $\mathrm{PHB}^{-4}$ harboring phaCcs could utilize fructose for the production of $\mathrm{P}(3 \mathrm{HB})$ homopolymer. The CDW $(3.1 \pm 0.2 \mathrm{~g} / \mathrm{L})$ and PHA content $(64 \pm 2 \mathrm{wt} \%)$ was almost similar to that of wild type $C$. necator $\mathrm{H} 16$ (3.3 $\pm 0.1 \mathrm{~g} / \mathrm{L}$ and $56 \pm 1 \mathrm{wt} \%$ ). The TEM micrograph in Figure 2 further confirms the formation of PHA granules in the recombinant. The bacterium was packed with large quantities of distinctly visible granules, resulting in the cells to appear elongated. As expected, no PHA accumulation was observed in $C$. necator $\mathrm{PHB}^{-} 4$ harboring only the plasmid pBBR1MCS-2 without the synthase gene. Higher CDW was obtained when CPKO was used as the sole carbon source. The cell biomass of recombinant harboring phaC $C_{\mathrm{Cs}}$ was $4.0 \pm 0.2 \mathrm{~g} / \mathrm{L}$. However, the PHA content was almost similar as when fructose was used.

Interestingly, in the presence of $\mathrm{CPKO}$, accumulation of $\mathrm{P}(3 \mathrm{HB}-\mathrm{co}-3 \mathrm{HHx})$ copolymer with $4 \mathrm{~mol} \%$ of $3 \mathrm{HHx}$ was observed in the recombinant $C$. necator $\mathrm{PHB}^{-} 4$ harboring phaCcs. This was not evident in the wild type Chromobacterium sp. USM2. Previously, Kolibachuk and co-workers noticed that $3 \mathrm{HHx}$ monomer was accumulated by recombinant $C$. necator $\mathrm{PHB}^{-} 4$ harboring the PHA synthase gene of $C$. violaceum when fed with even carbon numbered fatty acids (Kolibachuk et al., 1999). Similar studies were also done to generate $3 \mathrm{HHx}$ monomer by expressing PHA synthase gene of $A$. caviae in mutant $C$. necator $\mathrm{PHB}^{-} 4$ (Fukui and Doi, 1997). $A$. caviae is known to synthesize both SCL and MCL PHA containing four to six carbon atoms (Shimamura et al., 1994). Various plant oils including palm oil products have been used to produce $\mathrm{P}(3 \mathrm{HB}-\mathrm{CO}-3 \mathrm{HHx})$ copolymer from the recombinant $C$. necator $\mathrm{PHB}^{-4} 4$ harboring the $\mathrm{PHA}$ synthase gene of $A$. caviae (Fukui and Doi, 1998; Kahar et al., 2004; Loo et al., 2005). The generation of a new monomer in a different host could be associated with the occurrence and substrate specificity of enzymes. The expression of a foreign gene in a microorganism might result in the formation of additional enzymes or same enzymes with different substrate specificity towards the expressed gene compared to that of in the wild type microorganism. Besides this, availability of additional metabolic pathway in the new host might influence the production of PHA and its monomers. The factors mentioned above might have facilitated the incorporation of $3 \mathrm{HHx}$ monomer when phaC $C_{\mathrm{Cs}}$ was expressed in $C$. necator $\mathrm{PHB}^{-} 4$ using its native $p h a A$ and $p h a B$ genes.

To investigate the production of $\mathrm{P}(3 \mathrm{HB}-\mathrm{CO}-3 \mathrm{HV})$ copolymer, sodium valerate was added to the culture supplemented with fructose (Table 3). The 3HV composition generated by the recombinant harboring phaC $C_{\mathrm{Cs}}$ gene was nearly 2 -fold higher compared to the wild-type $C$. necator. The PHA content produced by this recombinant was also higher at $57 \pm 2 \mathrm{wt} \%$ compared to 
the wild type $(38 \pm 2 w t \%)$. These results indicated the affinity towards the incorporation of $3 \mathrm{HV}$ by the PHA synthase of Chromobacterium sp. USM2. High 3HV composition has been achieved using wild-type $C$. necator from selected 3HV-precursors or mixtures of these precursors with sugar. However, the high $3 \mathrm{HV}$ composition is mostly achieved by feeding higher concentration of precursors, up to $4-20 \mathrm{~g} / \mathrm{L}$ (Doi et al., 1988; Ramsay et al., 1990; Madden et al., 1998; Volova and Kalacheva, 2005). The ability of the PHA synthase of Chromobacterium sp. USM2 to accumulate high amount of $3 \mathrm{HV}$ from lower concentration of precursor $(2.5 \mathrm{~g} / \mathrm{L}$ of
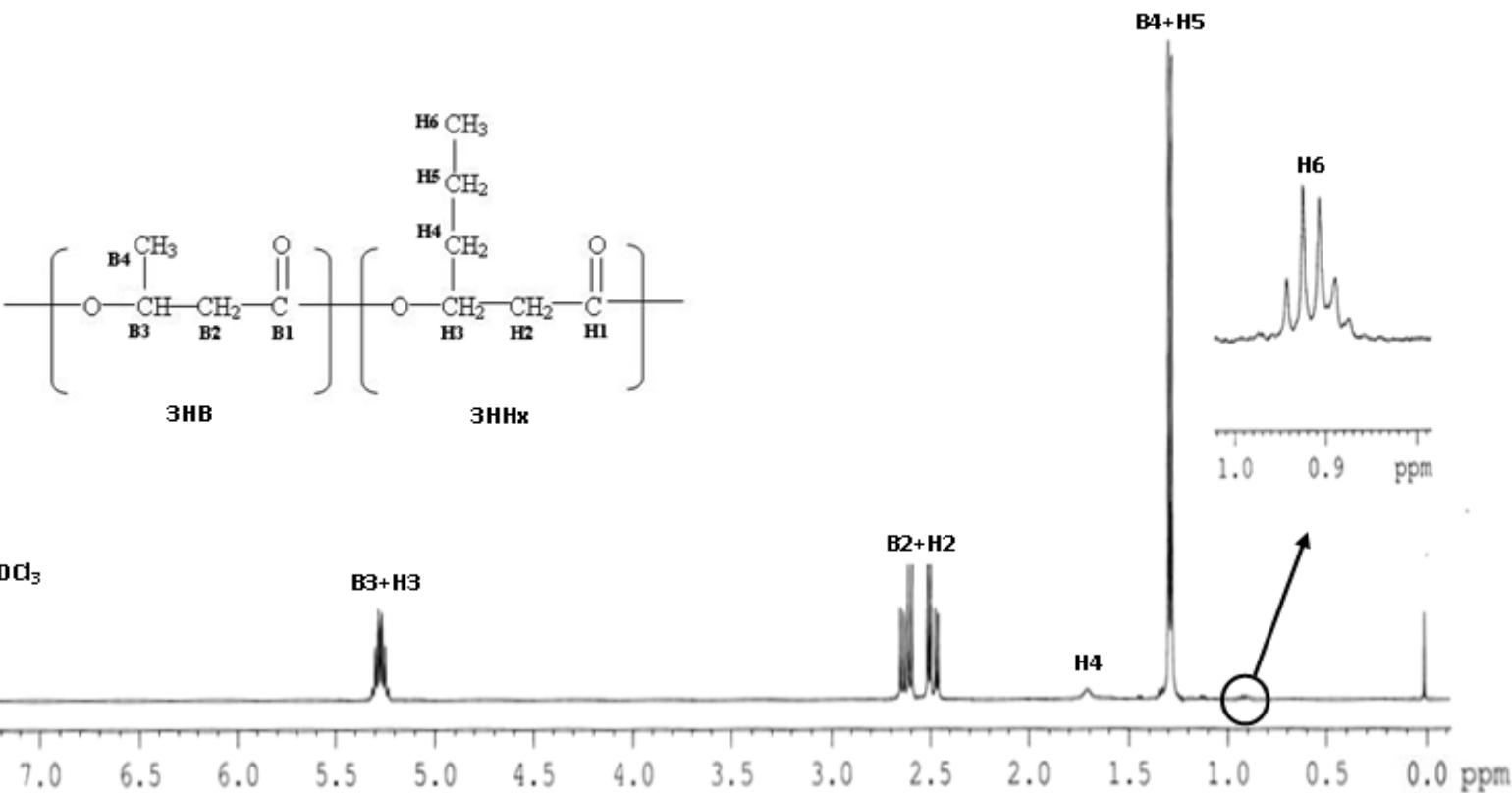

Figure 3: ${ }^{1} \mathrm{H}$ NMR spectrum confirming the presence of $3 \mathrm{HHx}$ monomer in $\mathrm{P}(3 \mathrm{HB}-\mathrm{co}-3 \mathrm{HHx})$ copolymer produced by $C$.
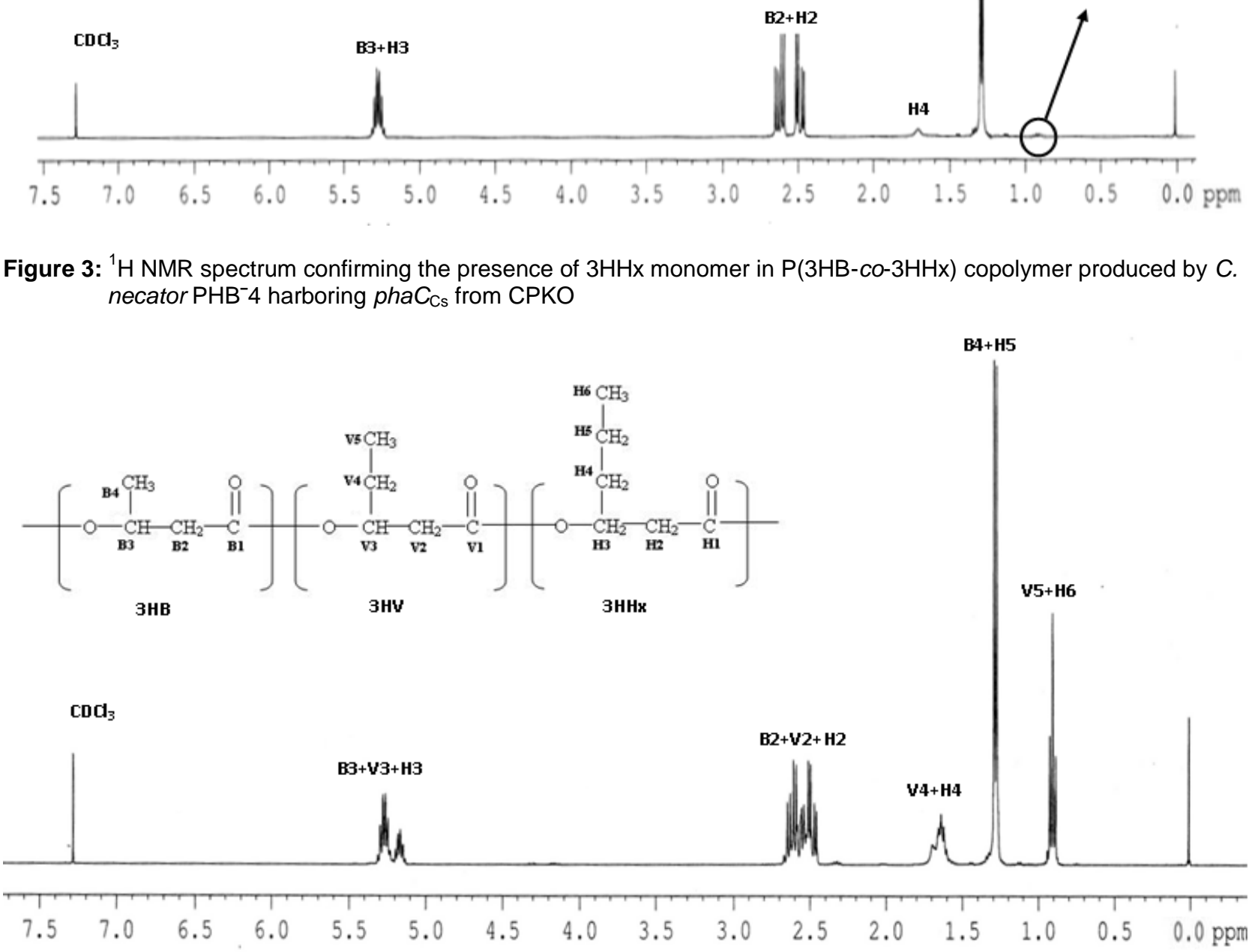

Figure 4: ${ }^{1} \mathrm{H}$ NMR spectrum confirming the presence of $3 \mathrm{HV}$ and $3 \mathrm{HHx}$ monomers in $\mathrm{P}(3 \mathrm{HB}-\mathrm{co}-3 \mathrm{HV}-\mathrm{co}-3 \mathrm{HHx})$ terpolymer produced by $C$. necator $\mathrm{PHB}^{-} 4$ harboring pha $C_{\mathrm{Cs}}$ from mixture of $\mathrm{CPKO}$ and sodium valerate 
sodium valerate) could reduce inhibitory effects towards cell growth and polymer accumulation.

Addition of sodium valerate in the presence of CPKO generated poly(3-hydroxybutyrate-co-3hydroxyvalerate-co-3-hydroxyhexanoate) [P(3HB-co-3HVco-3HHx)] terpolymer. Previously, production of $\mathrm{P}(3 \mathrm{HB}-$ co-3HV-co-3HHx) terpolymer had been investigated from palm kernel oil and mixtures of sodium valerate or propionate by using recombinant $C$. necator $\mathrm{PHB}^{-} 4$ harboring the PHA synthase of $A$. caviae (Bhubalan et al., 2008). The terpolymers were found to have interesting properties due to the incorporation of both $3 \mathrm{HV}$ and $3 \mathrm{HHx}$ monomers. Similar study was also done by Park and coworkers whereby the PHA biosynthesis genes of Aeromonas were heterologously expressed in recombinant E. coli (Park et al., 2001). They used dodecanoic acid plus odd carbon number fatty acid for the generation of $\mathrm{P}(3 \mathrm{HB}-\mathrm{co}-3 \mathrm{HV}-\mathrm{co}-3 \mathrm{HHx})$ terpolymer.

This recombinant was able to produce $42 \pm 2$ wt\% of polymer containing $87 \mathrm{~mol} \% 3 \mathrm{HB}, 9 \mathrm{~mol} \% 3 \mathrm{HV}$ and 4 $\mathrm{mol} \% 3 \mathrm{HHx}$, respectively. It was found that, the $3 \mathrm{HV}$ monomer composition generated in the presence of CPKO was lower compared to when fructose was used. This could be explained by the different monomer biosynthesis pathways that are being used to convert the substrates into PHA. In the presence of a mixture of fructose and sodium valerate, only sodium valerate enters the $\beta$-oxidation pathway for the synthesis $3 \mathrm{HV}$ monomer. However, both CPKO and sodium valerate simultaneously enter the $\beta$-oxidation pathway for the synthesis of $3 \mathrm{HB}$, $3 \mathrm{HV}$ and $3 \mathrm{HHx}$ monomers (Bhubalan et al., 2008). Hence, the generation of $3 \mathrm{HV}$ monomer might be affected due to the competition in monomer synthesis. The $3 \mathrm{HV}$ composition produced by this recombinant from mixture of CPKO and sodium valerate was almost similar with the value reported by Lee and co-workers during $\mathrm{P}(3 \mathrm{HB}-\mathrm{co}-$ $3 \mathrm{HV}$ ) copolymer production using wild-type $C$. necator and the same mixture of carbon source (Lee et al., 2008). However, in this study only half the amount of sodium valerate $(2.5 \mathrm{~g} / \mathrm{L})$ was used compared to the initial concentration of $5 \mathrm{~g} / \mathrm{L}$ which was used by Lee et al. (2008).

Nevertheless, it is possible to attain terpolymers with a wider range of $3 \mathrm{HV}$ monomer composition. The $3 \mathrm{HV}$ monomer composition in $\mathrm{P}(3 \mathrm{HB}-\mathrm{co}-3 \mathrm{HV}-\mathrm{co}-3 \mathrm{HHx})$ terpolymers are known to be varied by altering the concentration of $3 \mathrm{HV}$-precursor and its feeding time (Bhubalan et al., 2008). Prolonged cultivation period might also enable a more efficient conversion of precursor substrate to $3 \mathrm{HV}$ monomer as in this study the cultures were only incubated for $48 \mathrm{~h}$. Therefore, controlled synthesis of $\mathrm{P}(3 \mathrm{HB}-\mathrm{co}-3 \mathrm{HV}-\mathrm{co}-3 \mathrm{HHx})$ terpolymers using this recombinant could be further investigated in future studies.

In order to further verify the presence of $3 \mathrm{HHx}$ in the copolymer and $3 \mathrm{HV}$ and $3 \mathrm{HHx}$ monomers in the terpolymer chain, ${ }^{1} \mathrm{H}$ NMR analysis was carried out. From the spectra in Figures 3 and 4 , the presence of $3 \mathrm{HB}, 3 \mathrm{HV}$ and $3 \mathrm{HHx}$ monomers were identified. Methyl proton resonance at $0.9 \mathrm{ppm}$ can be assigned to $\mathrm{CH}_{3}$ group from $3 \mathrm{HV}$ and $3 \mathrm{HHx}$ monomers. In addition, $\mathrm{CH}_{2}$ group at 1.7 ppm also indicates the presence of $3 \mathrm{HV}$ and $3 \mathrm{HHx}$ monomers in the terpolymer chain. The presence of $3 \mathrm{HV}$ monomer in the terpolymer could be correlated with an increase in the intensity of this peak. ${ }^{1} \mathrm{H}$ NMR results further confirmed the findings of $\mathrm{GC}$ analysis.

\section{CONCLUSIONS}

In this study, Chromobacterium sp. USM2 a locally isolated bacterium was found to be capable of accumulating $\mathrm{P}(3 \mathrm{HB}-\mathrm{CO}-3 \mathrm{HV})$ with high $3 \mathrm{HV}$ monomer composition. Its PHA synthase gene was successfully cloned and heterologously expressed in C. necator $\mathrm{PHB}^{-} 4$. Accumulation of $\mathrm{P}(3 \mathrm{HB}-\mathrm{CO}-3 \mathrm{HHx})$ copolymer was identified once the recombinant was supplemented with CPKO as the sole carbon source. In addition, the recombinant was also capable of biosynthesizing $\mathrm{P}(3 \mathrm{HB}-$ co-3HV-co-3HHx) terpolymer when a mixture of sodium valerate and CPKO was fed. Further study is needed to understand the ability of both the isolate and recombinant in the production of different types of PHA. The resulting polymers could be tailored and characterized to suit selected applications.

\section{ACKNOWLEDGEMENTS}

Authors acknowledge the SAGA research grant (C62) provided by the Academy of Sciences Malaysia. K.B. acknowledges National Science Fellowship awarded by The Ministry of Science, Technology and Innovation, Malaysia for financial support. We thank Dr. M. E. Kovach for providing the pBBR1MCS-2 plasmid used in this study. Generous supply of CPKO by Acidchem Int. Ltd. is acknowledged.

\section{REFERENCES}

Anderson, A. J. and Dawes, E. A. (1990). Occurrence, metabolism, metabolic role, and industrial uses of bacterial polyhydroxyalkanoates. Microbiological Reviews 54, 450-472.

Bhubalan, K., Lee, W. H., Loo, C. Y., Yamamoto, T., Tsuge, T., Doi, Y. and Sudesh, K. (2008). Controlled biosynthesis and characterization of poly(3hydroxybutyrate-co-3-hydroxyvalerate-co-3-

hydroxyhexanoate) from mixtures of palm kernel oil and 3HV-precursors. Polymer Degradation and Stability 93, 17-23.

Braunegg, G., Sonnleitner, B. and Lafferty, R. M. (1978). A rapid gas chromatographic method for the determination of poly- $\beta$-hydroxybutyric acid in microbial biomass. European Journal of Microbiology and Biotechnology 6, 29-37.

Brazilian Genome. (2009). [cited on $15^{\text {th }}$ January 2009]. http://www.brgene.Incc.br/cviolaceum/

Doi, Y. (1990). Microbial polyesters. Wiley-VCH, New York.

Doi, Y., Kitamura, S. and Abe, H. (1995). Microbial synthesis and characterization of poly(3- 
hydroxybutyrate-co-3-hydroxyhexanoate).

Macromolecules 28, 4822-4828.

Doi, Y., Tamaki, A., Kunioka, M. and Soga, K. (1988). Production of copolyesters of 3-hydroxybutyrate and 3-hydroxyvalerate by Alcaligenes eutrophus from butyric and pentanoic acids. Applied Microbiology and Biotechnology 28, 330-334.

Friedrich, B., Hogrefe, C. and Schlegel, H. G. (1981). Naturally occurring genetic transfer of hydrogenoxidizing ability between strains of Alcaligenes eutrophus. Journal of Bacteriology 147, 198-205.

Fukui, T. and Doi, Y. (1997). Cloning and analysis of the poly(3-hydroxybutyrate-co-3-hydroxyhexanoate) biosynthesis genes of Aeromonas caviae. Journal of Bacteriology 179, 4821-4830.

Fukui, T. and Doi, Y. (1998). Efficient production of polyhydroxyalkanoates from plant oils by Alcaligenes eutrophus and its recombinant strain. Applied Microbiology and Biotechnology 49, 333-336.

Kahar, P., Tsuge, T., Taguchi, K. and Doi, Y. (2004). High yield production of polyhydroxyalkanoates from soybean oil by Ralstonia eutropha and its recombinant strain. Polymer Degradation and Stability 83, 79-86.

Kolibachuk, D., Miller, A. and Dennis, D. (1999). Cloning, molecular analysis, and expression of the polyhydroxyalkanoic acid synthase (phaC) gene from Chromobacterium violaceum. Applied and Environmental Microbiology 65, 3561-3565.

Kovach, M. E., Elzer, P. H., Hill, D. S., Robertson, G. T., Farris, M. A., Roop, R. M. and Peterson, K. M. (1995). Four new derivatives of the broad-host-range cloning vector pBBR1MCS, carrying different antibiotic-resistance cassettes. Gene 166, 175-176.

Lee, W. H., Loo, C. Y., Nomura, C. T. and Sudesh, K. (2008). Biosynthesis of polyhydroxyalkanoate copolymers from mixtures of plant oils and 3hydroxyvalerate precursors. Bioresource Technology 99, 6844-6851.

Loo, C. Y., Lee, W. H., Tsuge, T., Doi, Y. and Sudesh, K. (2005). Biosynthesis and characterization of poly(3-hydroxybutyrate-co-3-hydroxyhexanoate) from palm oil products in a Wautersia eutropha mutant. Biotechnology Letters 27, 1405-1410.

Loo, C. Y. and Sudesh, K. (2007a). Polyhydroxyalkanoates: bio-based microbial plastics and their properties. Malaysian Polymer Journal 3, 31-57.

Loo, C. Y. and Sudesh, K. (2007b). Biosynthesis and native granule characteristics of poly(3hydroxybutyrate-co-3-hydroxyvalerate) in Delftia acidovorans. International Journal of Biological Macromolecules 40, 466-471.

Madden, L. A., Anderson, A. J. and Asrar, J. (1998). Synthesis and characterization of poly(3hydroxybutyrate) and poly(3-hydroxybutyrate-co-3hydroxyvalerate) polymer mixtures produced in highdensity fed-batch cultures of Ralstonia eutropha (Alcaligenes eutrophus). Macromolecules 31, 56605667.
McDowell, E. M. and Trump, B. F. (1976). Histologic fixatives suitable for diagnostic light and electron microscopy. Archives of Pathology \& Laboratory Medicine 100, 405-414.

Ostle, A. G. and Holt, J. G. (1982). Nile Blue A as fluorescent stain for poly- $\beta$-hydroxybutyrate. Applied and Environmental Microbiology 44, 238-241.

Park, S. J., Ahn, W. S., Green, P. R. and Lee, S. Y. (2001). Biosynthesis of poly(3-hydroxybutyrate-co-3hydroxyvalerate-co-3-hydroxyhexanoate) by metabolically engineered Escherichia coli strains. Biotechnology and Bioengineering 74, 81-86.

Ramsay, B. A., Lomaliza, K., Chavarie, C., Dubé, B., Bataille, P. and Ramsay, J. A. (1990). Production of poly-( $\beta$-hydroxybutyric-co- $\beta$-hydroxyvaleric) acids. Applied and Environmental Microbiology 56, 20932098.

Sambrook, J., Fritsch, E. F. and Maniatis, T. (1989). Molecular cloning laboratory manual. $2^{\text {nd }}$ ed. Cold Spring Harbor Laboratory Press, Cold Spring Harbor, New York.

Shimamura, E., Kasuya, K. I., Kobayashi, G., Shiotani, T., Shima, Y. and Doi, Y. (1994). Physical properties and biodegradability of microbial poly(3hydroxybutyrate-co-3-hydroxyhexanoate). Macromolecules 27, 878-880.

Simon, R., Priefer, U. and Pühler, A, (1983). A broad host range mobilization system for in vivo genetic engineering. Transposon mutagenesis in Gram negative bacteria. Bio/ Technology 1, 784-791.

Spurr, A. R. (1969). A low-viscosity epoxy resin embedding medium for electron microscopy. Journal of Ultrastructure Research 26, 31-43.

Steinbüchel, A., Debzi, E. M., Marchessault, R. H. and Timm, A. (1993). Synthesis and production of poly(3hydroxyvaleric acid) homopolyester by Chromobacterium violaceum. Applied Microbiology and Biotechnology 39, 443-449.

Steinbüchel, A. and Lütke-Eversloh, T. (2003). Metabolic engineering and pathway construction for biotechnological production of relevant polyhydroxyalkanoates in microorganisms. Biochemical Engineering Journal 16, 81-96.

Sudesh, K., Abe, H. and Doi, Y. (2000). Synthesis, structure and properties of polyhydroxyalkanoates: Biological polyesters. Progress in Polymer Science 25, 1503-1555.

Sudesh, K. and Iwata, T. (2008). Sustainability of biobased and biodegradable plastics. CLEAN 36, 433-442.

Vasconcelos, A. T. R., Almeida, D. F., Hungria, M., Guimarăes, C. T., Antǒnio, R. V., Almeida, F. C., (2003). The complete genome sequence of Chromobacterium violaceum reveals remarkable and exploitable bacterial adaptability. Proceedings of the National Academy of Sciences of the United States of America 100, 11660-11665.

Vigneswari, S., Vijaya, S., Majid, M. I. A., Sudesh, K., Sipaut, C., Azizan, M. N. M., Amirul, A. A. A. (2009). Enhanced production of poly(3- 
Mal. J. Microbiol. Vol 6(1) 2010, pp. 81-90

hydroxybutyrate-co-4-hydroxybutyrate) copolymer with manipulated variables and its properties. Journal of Industrial Microbiology Biotechnology 36, 547-556.

Volova, T. G. and Kalacheva, G. S. (2005). The synthesis of hydroxybutyrate and hydroxyvalerate copolymers by the bacterium Ralstonia eutropha. Microbiology 74, 54-59. 